\title{
THE MEASUREMENT OF CRIME IN THE UNITED STATES
}

\author{
HARRY MANUEL SHULMAN
}

\begin{abstract}
The author is Professor of Sociology at the City College of the City University of New York. Among his many publications are Juvenile Delinquenty in American Sociely (1961), Shums of New York (1938), and a series of research monographs on the causation and social control of juvenile delinquency and youth crime, published by the New York State Crime Commission (1926-1931). He was on leave, 1954-1956, to serve as First Deputy Commissioner of Correction in New York City. In 1964-1965 he was consultant on criminal statistics to the Office of Statistical Standards, U. S. Bureau of the Budget, Washington, D. C.

Professor Shulman's article is based upon a paper he presented at the International Congress of Criminology in Montreal, Canada, on September 3, 1965. In it he reviews critically the current American practice of depending heavily upon police statistics as the national measure of crime, describes police statistics as a product of the very limited function exercised by the police in American crime control, and urges the extension of crime measurement to the full volume of sanctionable offenses dealt with by administrative and regulatory agencies, in the areas of administrative and civil law as well as those arising under criminal law. He also proposes a continuing review of data in sources of information on unreported crimes and offenses. Finally, he recommends the establishment of a central federal facility, under a professionally trained staff of criminologists, to direct the collection, analysis and publication of American criminal statistics.
\end{abstract}

Crime is by its very nature not easily measureable, being subject to concealment and nonreporting-concealment by victims and nonreporting by authorities-and, as a result, the reported statistics of crime are ordinarily far short of the full volume and range of offenses. This situation holds true for the United States, in which there is as yet no comprehensive, co-ordinated body of national crime statistics, and whose reported crime statistics, compiled by a variety of agencies, fail to provide an accurate statistical base for the analysis of the volume, categories, and trends of crime in the nation.

The primary reporting of crimes in the United States lies in the hands of local police departments, who submit statistics of complaints and arrests to the Federal Bureau of Investigation of the United States Department of Justice. There are many inadequacies in this reporting process, some of which will be described later, but the underlying defect of police reporting as a measure of the volume of crime is that the police have only a very limited function in crime control, and the crimes reported by the police are only a fraction of those that occur. Important segments of crime are dealt with, not by criminal justice agencies under the auspices of criminal law but by regulatory agencies under the auspices of administrative and civil law, whose findings are hidden in the obscure and di- verse reports of fifty sovereign States and the Federal government. Finally, many aspects of crime result in no official complaint to any form of sanctioning authority-criminal, administrative or civil-but only come to light through the operations of public departments and private agencies concerned with education, health, welfare and safety, and of private agencies and rassociations that serve the economic interests of many different occupations and industries.

As the result of the lack of a national policy for the comprehensive co-ordinated reporting of crime in the United States, governmental commissions and agencies assigned to the study of law enforcement and crime prevention labor under the handicap of a lack of the fundamental scientific data necessary for the study of the relationships between social policy and crime control as well as the study of the efficacy of agencies for the administration of justice. At the same time, social scientists lack the data necessary for sound national epidemiological and etiological studies of crime.

\section{The Cóncealument and Non-Reporting OF CRane}

Wide areas of criminal behavior fail to be included in crime statistics because of ambivalences and social resistances toward their reporting to sanctioning agencies, and because of opportunities for their concealment. 
In sex and family relationships there is a myriad of unreported cases in which the criminal law is often in conflict with social norms and private human emotions, viz.: in homosexual relations, seduction and statutory rape, fornication and adultery, illegal abortion, bastardy (illegitimacy), miscegenation, and desertion and non-support.

Among the independent professions there are large numbers of unreported violations of law both among clients and practitioners. In the medical profession alone there are unreported illegal abortions, illegal prescriptions of narcotic drugs and illegal child adoption practices, to say nothing regarding unethical if not downright illegal practices of fee-splitting and unnecessary medical care. In the practice of law there are falsifications of claims, perjury and subornation of perjury, mingling of client's funds with those of the practitioner, and conflicts of interest.

Among the independent professions, in retail trade, and in fact wherever there is the opportunity for cash transactions, there are concealments of income for the purposes of income and excise tax evasions. Despite their undoubted frequency, very few criminal tax evasions actually become known as crimes.

Among employees there are frequent embezzlements and thefts of goods and materials commonly dealt with not by arrest and prosecution but by dismissal and sometimes by restitution. Embezzlements go unreported because supervisors are themselves guilty of related or comparable offenses. Many times, employee thefts, resulting in inventory shrinkages, are written off as customer dishonesty.

Dishonesty among customers, such as the common offenses of shoplifting and petty check forgery are ordinarily not dealt with by criminal complaint and prosecution. Shoplifting, a common and widespread customer offense, committed by housewives and 'teen-agers who are not necessarily poverty-stricken, as well as by indigents and experienced thieves, is often dealt with by department and specialty stores in the form of confiscation of the stolen goods, warnings, and sometimes by the requirement of signed confessions that are filed for the purpose of prosecution in the case of repetition of the offense on the same premises. The issuance of forged and fraudulent checks for small amounts by customers against local merchants is usually charged to profit and loss for fear of harm to community good-will arising from the prosecution of local residents.
The laws on public policy in the field of gambling are violated with impunity by millions of the general public in urban society, who in this fashion often unwittingly support criminal syndicates who monopolistically control dangerous subsidiary rackets in prostitution, narcotics, bootlegging, and usury, offenses that have their own non-reporting clientele and victims.

Among public officials and employees there are many criminal acts of omission and commission, the most common being the acceptance of bribes to grant favors in violation of law and to overlook violations. In municipal government, licensing authorities, housing inspectors, and inspectors of health hazards and dishonest weights and measures, engage often in practices of corruption without too great a danger of being caught.

Together, the crimes and offenses committed in the areas of sex and family relationship, and by professionals, business men, landlords, taxpayers, employees, customers and the general public probably number in the tens of millions of cases and must far outweigh in volume and monetary loss the offenses that are the subject of police action. Whereas there is little evidence of these offenses in the known criminal statistics, there is a large number of subsidiary sources of information from which estimates of volume and trend could be derived. There is evidence from the medical profession, the clergy, departments of education, health and welfare, and from private social agencies regarding the extent of unreported offenses in the areas of sex and family relationship, even though the identity of specific offenders may be shielded by the confidential status of the information and of the records in which they are located.

Investigative reports by legislative and other governmental commissions, in the fields of industrial medicine and insurance fraud, not to mention a variety of other violations in the fields of food and drugs, employer-employee relationships, union management, etc., are data sources. Reports of insurance underwriters and fire marshals give evidence of arson. The files of the Internal Revenue Service hold evidences of tax dishonesty, but they are not open to outside study; and relatively few have been prosecuted as crimes. Reports from trade associations throw light upon dishonest practices by employees and customers and give evidence of the extent of certain rackets, such as the bootleg manufacture, distribution, and sale of untaxed liquor. 
The records of agencies of municipal government, such as those of health, housing and fire, could throw a flood of light upon violations of municipal codes on licensing and occupancy reported by inspectors but neither made the subject of sanctions nor reported in public statistics. Consumer complaints of dishonesties in retail advertising and of frauds in installment selling, reported to Better Business Bureaus, are a data source. At the present time hardly any of these sources, with the exception of legislative inquiries into organized crime, are tapped for national estimates of the amount of unreported, unrecorded, and unpunished crimes and offenses.

\section{Reported Crtams and Offenses Deatt Wrth} UNDER ADMMNISTRATIVE AND

\section{CrviL LaW}

There are many specialized forms of reported crimes and offenses whose punitive sanctions lie not in the criminal law but in the realm of administrative and civil law. Among these are offenses in commerce and industry, managementlabor relations, union management, income tax reporting, and social security and public assistance. Some of these offenses are dealt with by regulatory agencies of the states, but the majority are dealt with by the federal government under its interstate commerce powers. These include the Internal Revenue division of the Department of the Treasury, the National Labor Relations Board, the Federal Trade Commission, the Securities and Exchange Commission, etc. Some of these offenses are dealt with under anti-monopoly laws, such as the Sherman Act, which specifically defines violations as misdemeanors and permits criminal sanctions against corporation officers, but many others are dealt with under other administrative laws whose sanctions are directed only against the corporations themselves, through stipulations and cease and desist orders, fines, and confiscations of goods deemed unfit for public sale or consumption. Still others are dealt with under civil laws that permit punitive damages to injured parties.

Among reported offenses in commerce and industry - in the fields of finance, securities, manufacturing, communications, real estate, etc.-are restraints of free competition through illegal mergers, collusive price-fixing and bidding, market control through cartels, discriminatory rebates to favored customers, fraudulent advertising claims, and violations of a wide range of legislation regulatory of real estate-including rent controls, non- discrimination in rentals, and the maintenance of commercial and dwelling structures-so as to assure the health, welfare and safety of tenants.

In management-labor relations offenses include collusive practices between management and racket-controlled unions that result in contracts below current wage scales in industries and geographic areas; management violations of the National Labor Relations Act, such as labor spying, improper pressures upon workers in connection with union representation elections, and the discharge of workers for labor unionization activities; and in labor union management, the use of force and illegality in the election of officers of locals and national unions, and corrupt practices in the administration of vast union pension and welfare funds.

In industry-consumer relations there are such offences as false labelling, misrepresentation of products, false weights and measures, adulteration of products, manufacture under unhygienic conditions, etc.

In the area of taxation, aside from such violations as the evasions of payment of excise taxes (on liquor, cigarettes, tobacco, etc.) which carry criminal law penalties, there are many other offenses, particularly in the area of taxes on income, in which, despite the generally high level of tax collection at source, or of withholding at source, there is extensive misrepresentation of income and dishonesty in declaration of deductions. The majority of the latter offenses are dealt with as civil offenses and punished by fines, with no statistical reporting of their number.

In the areas of social legislation-unemployment and industrial compensation insurance, social security and public assistance-under whose umbrella tens of millions of citizens and residents have coverage, there are many violations which are rarely discovered; and when discovered they are rarely dealt with by criminal prosecution. In the area of public assistance alone, for example, aid to the indigent, handicapped, children, and elderly indigent, which covers some five millions of persons, the files of public agencies would disclose many forms of illegality dealt with by other than criminal prosecution.

As indicated earlier, the statistics of law violation in most of these categories of criminal offense lie buried in agency files, and sometimes they are to be found in the annual reports of public agencies, but so scattered are these information sources that they are not easily available to scientific 
investigators, much less the press. Moreover, much of this information has remained in bureaucratic concealment under the pleas of confidentiality or national security and it will be released only when "right to know" legislation makes them available to the public. In the rare instances in which violations of court orders have resulted in punishments for contempt, or where prosecutions under federal criminal law has resulted in conviction, the statistics of conviction are to be found in the annual reports of the administrative office of the federal court system, but even here the statistics are so garbled that specific offenses, small in number but qualitatively significant, are concealed through inclusion in broader categories. What the total of this range of offenses may be, in commerce and industry, taxation and social legislation, is open to conjecture. Their gross volume must run into the millions of cases, of which only a relatively few are reported and dealt with under administrative and civil law, so that even a well-organized access to the statistics of reported cases would afford but a slight glimpse of their volume and characteristics.

\section{Crmies Known to the Police}

Only one body of crimes and offenses that occur in the United States is systematically reported on a national scale. These are the crimes known to the police and reported by them to the Federal Bureau of Investigation for publication in Uniform Crime Reports. Included among them are the major so-called common crimes of homicide, assault, robbery, burglary, and theft. These statistics have been given national prominence through regular distribution for the past thirty-five or more years in quarterly and annual reports and through regular conspicuous publication in the national press. As a result of this focus upon common crimes, as well as the constant cultural reference to and repetitious use of common crime themes in newspaper articles, radio, television, novels, detective stories, etc., the term crime has come to have an application almost entirely restricted to common crimes, and so respected has police crime reporting become that until recently mass communication agencies have given to their readers the impression that the statistics of common crimes are a scientific measure of the American crime volume.

From our previous discussion it should already be clear that this is not the case, and that crimes known to the police are a highly unrepresentative sample of American criminal offenses. The nature of this sample, evidences of its nonrepresentativeness even of common crime, and the legal, administrative and sociological circumstances that limit the function of the police in dealing with crime, and hence limit their role in crime reporting, call for some further discussion.

The police reporting of common crime consists of two markedly different sets of data, one of citizen complaints, i.e., "crimes known to the police", and the other of arrests. One refers to offenses and the other to persons, and there is no necessary statistical relationship between them since in some crimes a number of individuals may be involved and for others a single individual may have committed more than one offense.

There is markedly incomplete police reporting of offenses. Only seven serious forms of crime are regularly reported in Uniform Crime Reports: murder and non-negligent manslaughter, forcible rape, robbery, aggravated assault, burglary, larceny of $\$ 50$ and over, and auto theft. ${ }^{1}$ The remaining citizen complaints to the police are, with one exception (larceny of $\$ 50$ and under), not reported in Uniform Crime Reports, and are not comparable for either volume or trend, although the basic data exist in the files of individual police departments.

The police rationalization of this selective reporting of citizen complaints is that minor offenses tend not to be reported to the police and that only complaints of serious crimes, which are said to be more commonly reported, can serve as an Index of Crime. However, since the crime index concept is itself a dubious one, in the light of evidence that police records as a whole are a highly selective measure of crime, its use to explain the non-reporting of the majority of complaints in the 29-category schedule of crimes used in Uniform Crime Reports is itself highly dubious. This point will be elaborated.

The selective reporting of crime complaints leaves only one category of police crime data free from criticism on this score, i.e., that of arrest. By arrest is meant persons taken into custody and charged with a criminal offense, as differentiated from those merely questioned and released. In 1964, in a registration area comprising some 132 million persons, some 4,582,000 persons were

\footnotetext{
${ }^{1}$ The word serious as used in Uniform Crime Reports is somewhat of a value judgment, since it includes such offenses as the theft of automobiles for pleasure use, and petty thefts.
} 
arrested, of which close to $2,000,000$ arrests were either for drunkenness $(1,458,000$ cases) or disorderly conduct (475,000 cases). An additional 378,000 cases involved other aspects of drinking, viz.: driving under the influence $(225,000$ cases), and liquor law violations (153,000 cases). ${ }^{2}$ Thus, of $4,582,000$ arrests, some $2,311,000$, or more than 50 percent, involved either drunkenness or disorderliness, or both. It would thus be fair to state that the job of the police, as judged by these statistics, is largely to cope with drunken and disorderly persons, a task of some importance in the maintenance of public order and safety, but not one bulking large in criminal threat to the security of the society.

The next largest category of arrests is for larceny-theft (some 358,000 cases) of which the bulk were probably for thefts under $\$ 50$, and since arrests for larceny-theft bear a ratio of one arrest to every five complaints, or 20 percent, it can properly be stated that for this category arrests are a disproportionately low measure of predatory crime.

However, it is in the category of public policy arrests-for gambling, prostitution, and narcotics (offenses almost lacking in citizen complaint)that police arrest statistics can be most highly criticized as a measure of societal misconduct. In 1964 , in an urban registration area of some 3,000 cities, these offenses resulted in some 160,000 arrests $(98,000$ of gambling; 27,000 of prostitution; and 35,000 of narcotics), a somewhat impressive total until subjected to closer analysis. First of all, public policy arrests represented less than 4 percent (3.9 percent) of all arrests. The relative unimpressiveness of the statistics on public policy arrests becomes more apparent when their average distribution by cities is analyzed. ${ }^{3}$

Some 98,000 gambling arrests, distributed among some 3,000 cities, averaged out to 32 arrests per city per year, a figure that would include syndicate and independent operators, bookmakers, policy runners and collectors, customers, and repeated arrests of all these. Some 27,000 prostitution and commercialized vice arrests in the same number of cities averaged out to 9 arrests per city per year, a figure that would include overlords, madams, pimps, establishment prostitutes and street-

2 Uniform Crime Reports, Federal Bureau of Investigation, United States Department of Justice, 1964 Washington, D.C., 1965, p. 106.

${ }^{3}$ Inasmuch as arrest figures for individual cities were not reported, only averages can be calculated. walkers, and repeated arrests of all these, as well as (in some jurisdictions) patrons. Some 36,000 narcotic drug arrests in the same number of cities averaged out to some 12 arrests per city per year, for syndicate and independent operators, distributors, addict-sellers and addicts, plus repeated arrests.

The small number of arrests for public policy offenses in a field of criminal operation reputed to derive huge revenues (estimated from seven to twenty-two billions of dollars per year for gambling alone) for syndicated operators known as "families" would suggest that these low arrest figures are not to be taken as a serious measure of the volume of public policy offenses in the United States. When compared to the high volume of arrests in connection with drinking, the small proportion of arrests on public policy charges in a crime area that operates as a cancer in the American society, is suggestive of selective arrest patterns among the police of the United States.

Even these statistics, however, do not tell the entire story of selective public policy offense arrest patterns. Negroes, with some eleven percent of the national population, experience some 72 percent of all urban arrests for gambling, 53 percent of all urban arrests for prostitution and 40 percent of all urban arrests for possession of narcotics.

The evidence thus far is that many areas of crime are infrequently reported to the police, that in exercising their primary assignment of law enforcement the police make arrests primarily for drunkenness and disorderly conduct, and that they make relatively few arrests for larceny-theft and very few public policy arrests. Thus, neither citizen complaints nor arrests would appear to be sound measures of the volume of common crime in the United States. At best, perhaps, police statistics are a sound measure of only a handful of serious common crimes (homicide, rape, robbery, aggravated assault) in which there is both a high level of complaint as well as of arrest. Such conclusions raise questions as to the reasons for the selective nature of police crime statistics.

\section{Limitations of the Police as a CrTARe-Reporting Agency}

The police, although they are in theory assigned wide powers of law enforcement, yet limited by the laws of arrest and other civil liberties and constitutional rights of the citizenry, exercise in practice a very restricted law enforcement role. 
They are primarily a peace preservation body whose major functions are the protection of life, limb, and property on the streets and highways, in places of public assemblage and in commercial and private properties entered illegally from public ways. As we have seen, they exercise little or no enforcement functions in crimes of sex and the family, in commerce and industry, in tax evasion, in crimes by employees and customers, and in public policy crimes by the general public and the syndicates they support. For all of these other areas there exist alternate agencies of complaint and law enforcement, some within criminal law enforcement power, such as prosecutors and attorneys-general of the states and of the federal government, or within administrative law such as state and federal regulative agencies. Indeed, even in those areas of crime in which the police function most competently, those of common crime, the crime prevention function of the police is restricted to general patrol, and their detective function occurs after the crime has occurred in their absence. The only offenses in which they exercise both a preventive and a criminal justice function are those offenses which occur in their presence and those to which they are summoned while the offenses are in process.

The circumstances in American culture and social organization that assign to the police such a circumscribed function in law enforcement, and that permits a vast range of offenses to go unreported or to be dealt with by other investigative bodies, are numerous and, in a paper concerned primarily with the measurement of crime, can be mentioned only summarily. A wide operational range of powers for police is inconsistent with American ideological beliefs and principles of limited sovereignty. Our ideological attachment to civil liberties prevents assignment to the police of roving powers of investigation such as through the unregulated tapping of the mails and other instruments of communication. The police are restricted to the exercise of the police powers of the municipality or some other governmental body of which they are agents, and they have no national police powers such as are exercised by some European police. As a result, offenders whose operations extend beyond municipal, county, and State boundaries are not subject to arrest outside of the limited jurisdiction in which their primary offense occurred, except for purposes of extradition.

At the same time, the local police are subject to the rivalry of other separate and equal branches of government. Their authority is kept in close check by the legislative branch, which has invented alternate regulatory mechanisms via the administrative law for the control of a vast network of economic forces; they are in rivalry with prosecutor's offices in the handling of criminal complaints; and they are checked by the courts in their exercise of practices that interfere with civil liberties.

Local police departments in the United States function in communities sharply divided in social values on many issues of civil rights and personal morals. Not themselves ordinarily a cross-section of the racial and ethnic composition of the local population, they are called upon to adjudicate conflicts involving breaches of the peace that have overtones on the one hand of racial and ethnic antagonisms and, on the other, of violations of civil rights. In communities in which public policy crimes are not only the subject of culture conflict, but of political protection by corrupt political machines that have venal ties with fabulously wealthy criminal syndicates, the police are subject to many malignant controls and temptations.

Finally, the recruitment and training of the police as a highly technical career body of superior men and women is a policy that has had much lip service in American politics and little implementation. Ill-trained as most of them are, lacking in standards of high general education, and rarely selected for outstanding general intelligence, they have never had the undivided admiration and loyalty of the American public or even of the press. Because of these circumstances, together with the aforesaid legal restrictions upon their functions, they are rarely called upon to handle investigations that call for technical skill, rare judgment, tact, and administrative knowledge. Under these circumstances it is not surprising that the measure of their efficiency, as determined by the relationship of citizen complaints to arrests, and by their selective patterns of law enforcement through onsight arrest, is low.

\section{Gaps, Discontinuities and Lmitrations in the Reporting of CRIME}

We may now pull together some of the gaps, discontinuities and limitations in the reporting of American crime. As has been indicated, vast numbers of offenses in many areas of misconduct are not included in any systematic totals of 
American crime volume. Nor are there adequate bodies of criminal statistics even among those arising among criminal justice agencies, i.e., the police, prosecutors and courts. The most extensive reporting system, that of Uniform Crime Reports, is deficient in many ways. Citizen complaints are reported for only eight of twenty-nine categories of offense. ${ }^{4}$ That series of categories, while appearing offhand to be sufficient for crime reporting, is actually very insufficient and conceals important categories of crime, wbich, because they are lumped with others, are in effect not reported at all. Thus, shoplifting, commercial crimes generally, and offenses involving landlords and tenants, are in this manner not reported. The latter category, which includes landlord complaints of vandalism and tenant complaints of persistent failure to provide basic services in housing tenancy, have a close involvement with other aspects of social disorganization and intergroup conflict in our rapidly urbanizing society and their reporting would serve a useful purpose in the study of conflicted human relationships in slum areas.

Other important offenses are not reported at all; for example, the only traffic offense reported is that of drunken driving. It is understandable that minor offenses involving stationary vehiclesparking ordinance violations, etc.,-can be safely ignored in national crime totals, but offenses involving moving vehicles such as speeding, passing on curves, driving by unauthorized persons or in unsafe vehicles, demand national reporting by reason of the large number of deaths from vehicular "accidents", some 50,000 annually, not to mention the hundreds of thousands of injuries and the monetary losses in property destruction and damage, hospital and medical bills and the loss of income and earning ability.

The use of complaints on only seven offenses in the Uniform Crime Reports as an index of crime is unwarranted in the light of our knowledge of the limited law enforcement functions of the police, and of the highly selective reporting by police of even those offenses over which they have primary jurisdiction. Under pressure, the Uniform Crime Reports has modified its claims to define these complaints as an index of common crime, and it is hypothesized that all other common crimes reported in police statistics vary in level as these

4 Since the present paper was originally delivered some few changes have taken place in the composition of the 29 categories, but the number remains the same. seven do. Unfortunately, however, this hypothesis is not verifiable, because in order to use a sample as an index we must know the size and composition of the universe from which the sample was drawn and we must have assurances that the sample was a representative one. From our preceding discussion we know that the universe of crime in our society is largely unknown, both as a whole and in its particulars, and that the police sample is likely to be unrepresentative, not only in its concentration upon certain categories of crime, but owing to the fact that those categories are unduly drawn from the offenses of certain racial and ethnic minorities and social classes.

Actually, the so-called "index to crime" projects predictively only a part of even that portion of crime with which the police come into contact and serves no other predictive function than to suggest what the future of those seven offenses may be. Its claimed use as a general crime predictive instrument has never been verified, is not verifiable and should not be used by the federal government in any manner, since its use tends to conceal the fact that in truth we do not now know either the whole volume or trends of crime in the United States, in part because it is not knowable, and in part because that portion which is known has never been properly organized for analysis.

As has been indicated, many complaints by-pass the police and are reported directly to prosecutors and attorneys-general of the states and federal government, and these often comprise offenses of far greater importance to the public than those reported to the police. Thus, the range of victims may be greater. They include, for example, complaints against conspiracies such as syndicated operations in public policy crime, in labor union management, in labor-management relations, in manager-consumer relationships, within industries, and conspiracies in the operation of criminal justice itself. Complaints to prosecutors and attorneys-general, however, tend not to be systematically reported, being usually anecdotal and focussed upon dramatic cases, rather than statistical and analytical.

The judicial statistics of those cases that come to trial in the courts could throw a great deal of light upon the criminal justice process, but in most of the states these are not reported on a state-wide basis and are, as a result, not accessible for reporting and analysis. 
The listing of three levels of criminal statistics, those of the police, prosecutors, and courts, defines the structure of criminal statistics necessary for the reporting of criminal complaints in any geographical and political jurisdiction and for an analysis of the criminal justice process in that jurisdiction. The flat statement can be made that in most jurisdictions this structure of criminal statistics is not available in a form convenient for criminological purposes, and is therefore not used for analytical studies. This situation is almost as true for the federal government as it is for the states.

At the federal justice level there exist administrative data at each stratum of operation, but these are neither systematically reported as criminal statistics nor made available to any central collecting agency for reporting and analysis. A handful of federal offenses are dealt with by federal marshals, who function as police and have jurisdiction over federal lands and properties. They issue no systematic reports of complaints or arrests. The major body of important federal criminal law offenses is dealt with by federal prosecutors, who issue no systematic reports of criminal complaints and their dispositions, either individually or as a whole. Another significant body of criminal complaints and dispositions arises among the armed forces, consisting of violations of civil and military law among a large group of young men of high actuarial crime risk. However, the statistics of their offenses, as handled within the military chain of command, are not available for public use, being issued only for intramural information by the Department of Defense. And, as has been indicated, a wide range of offenses against administrative and civil law carrying punitive sanctions, and handled by administrative and regulatory agencies of the Federal government, are not available as collected statistics. Only the Administrative Office of the United States courts issues valuable annual statistics of those criminal complaints that are tried in the United States District Courts, but in the absence of complaint totals and their dispositions from all federal prosecutors, these tell little regarding the volume of federal criminal law complaints and their processing. As a result of this failure to collect under one roof all statistics of federal offenses, even the United States government has no systematic information on its own system of criminal and administrative law procedures.
Steps Toward the Improved Collection and

\section{ANALYSIS OF AAIERTCAN \\ Crmminal Statistics}

If American criminal statistics are to become available for (a) epidemiological studies of volume, distribution, and trends within functional settings of the cultural, economic and political organizations of the society; (b) administrative studies of the investigative and judicial process in this volume of cases; and (c) studies of the relationship of law enforcement policies and practices to crime prevention and control, it is apparent that significant changes in their collection, reporting and analysis will have to be made, involving at the very least the following procedures:

(1) Synthesis of the presently available statistics of sanctionable violations of criminal, administrative and civil law, now scattered in the many reports of Federal, State and local policing and regulatory agencies;

(2) The collection and synthesis from the files of many agencies of unreported data indicative of the volume of sanctionable law violations, not now the subject of complaint; and

(3) Raising the technical standards of the procedures for the measurement of American crime by placing its collection, analysis and reporting in the hands of criminologically trained research personnel qualified in the methods of social science research and statistical analysis.

The first step (1) requires the designation of a federal department or agency as the center of analysis and reporting of all available American criminal statistics. The second step (2) calls for such policies by that agency that the data indicative of unreported violations would be made available for study by other public and private agencies. The third step (3) the assignment of criminal statistics collection analysis and reporting to highly qualified social science analysts, calls for some discussion.

The sociological study of criminal statistics has by now reached a relatively high level of sophistication, both theoretically and methodologically. ${ }^{5}$ But so far there has been little utilization of this available skill in the field of criminal justice. Not since the 1930's, when federal and state commissions for the study of justice and law enforcement made systematic studies of criminal statistics has

'Selin \& Wolfgang, The Measurement of Delinguency (1964). 
there been a proper emphasis upon the public utilization of sound social science methods and of a qualified professional personnel in their collection and analysis. ${ }^{6}$ Currently, at every level in the criminal justice process-in the police, prosecutor's offices, courts, correctional agencies, and rehabilitative agencies such as probation and parole departments-the task of criminal statistics has been largely in the hands of persons lacking the training for that exacting specialization.

It is conceivable that the steps here proposed may be initiated in the near future, but it is necessary that there be an awareness of the resistances in our society against systematic scientific reporting of crime. Some of these resistances originate in the opposition of strong vested interests, and others have their roots in our historical traditions. There are resistances, for example, among some criminal justice agencies who object to scientific measures of their efficiency. Thus, the honesty of police reporting of complaints has been from time to time called into question by the Federal Bureau of Investigation, which has had to reject the statistics of police departments which have sought to increase the measure of their own efficiency through under-reporting of citizen complaints as compared to arrests. Other resistances are latent in the industries subject to regulation by governmental bodies. Still other resistances exist in the administration of criminal justice, which is increasingly under criticism for its very high proportion of convictions without formal trial, on a plea of guilt to lesser offenses. Supportive of these resistances is a public opinion on the subject of law enforcement having its origin in the crime definitions of an earlier simpler society.

\section{Historical Backgrounds of OUR Patterns of CrIAE REPorting}

The American bias in favor of the reporting of "crime in the streets" as the single important category of crime has its historical antecedents. Nineteenth century American criminal law and criminal justice procedures were based upon the precedents of eighteenth century American colonial criminal law and institutions, which were in turn based upon earlier English models in common and statute law, made known to us through the writings of such commentators as Blackstone. The English

${ }^{6}$ Report on Criminal Statistics, National Commission on Law Observance and Enforcement, Washington, D. C., 1931. society from which we derived our models of criminal law was a monarchical aristocratic society, rural and agrarian in its major economic base, founded on the rights and privileges of a landed aristocracy and devoted in its commercial operations to the principles of mercantilism and monopoly.

In such a society, as it moved into a rapid industrialization and urbanization, under the influences of a growing population and a revolution in agriculture, together with the rise in inventions, the ensuing social disorders of poverty-stricken masses newly torn from the controls and protections of a rural agricultural economy were the focus of law enforcement efforts. Such a society found it natural to define crime principally in terms of the felonies and misdemeanors of the lowest, i.e., the poorest classes, and to view criminal justice as the protection of the sound and substantial elements of society against its enemies.

At the same time, as a nation with long historical traditions of civil liberties and an elective upper and middle class Parliament, the English were opposed to the exercise of broad police powers by its central government and even the powers of the small civilian police force concerned with common crimes remained sharply curtailed.

All of these principles and practices in criminal law and criminal justice administration were taken over in American criminal justice by a young nation that had suffered from arbitrary colonial government but which was itself ambivalent upon issues of republicanism and democracy. However, the latter half of the Nineteenth and the first half of the Twentieth century saw many economic and social changes in American society. From having been largely an agrarian homestead society of independent farmers and pioneers, the United States after the Civil War shifted rapidly to the industrial form of urban economy, corporate enterprise, joint stock ownership, technical management and unionized labor force. In such a society a criminal law based upon the control of highwaymen and felons was insufficient for social control and was augmented by much new legislation in other areas of social protection.

During the latter decades of the Nineteenth and early decades of the Twentieth century protections were written into law against the dangers of the unregulated factory system, for women and children, and for all labor through safety regulations, hour and wage regulations, and finally, 
through union recognition and the governmentsupervised process of collective bargaining. At the same time a mass of new regulatory laws was enacted for the control of monopolistic practices in commerce and industry and frauds in the sales of corporate securities; and the Federal government took giant steps toward the control of interstate commerce through the establishment of regulatory agencies for the control of aviation, communications, transportation, banks and trust companies, food and drugs industries, utilities, extractive industries, etc.

All of these innovations were consummated under the aegis not of criminal law but of administrative law, a hybrid partaking of some of the characteristics of civil law, by which agencies of government defined positively the procedures that regulate lawful commerce and industry, and some of the characteristics of criminal law, that define the punishments for the violation of administrative regulations. By the removal of commerce and industry controls from criminal law, corporations and their management were freed from the harsh criminal law mechanisms of the police, grand juries, prosecutors, courts and prisons, and, save in extreme instances, they were dealt with by the polite mechanisms of cease and desist orders, stipulations and consent decrees, supplemented by contempt of court proceedings for failure to comply with agency requests and orders.

Removal of the controls over commerce and industry from criminal law to administrative law jurisdictions resulted in ameliorations other than the substitution of fines and confiscations of contaminated goods when agency orders were disobeyed or ignored. The transfer of hearings from open courts to private agency offices screened corporations from the public ventilation of their misconduct, initially by removal from the observation of the public as observers, later by re- moval from the statistics of criminal justice agencies, and, most importantly, from the constant scrutiny of the press and other communication agencies.

The Twentieth century fractional reporting of crime in terms of the "man in the street" crimes of the lowest classes does violence to the full facts of criminal behavior in our society and substitutes a "cops and robbers" image of the offender as a professional criminal or social deviate, whereas in truth the majority of offenders are drawn from all social classes and all occupations. The effects of such a skewed statistical reporting of crime are many and significant. First and foremost, it reenforces the belief in a punitive approach to the control of crime by emphasizing the crimes of those who are not easily amenable to other forms of control. It shifts attention from crime as a product of the social order to concepts of its origin in constitutional defects and handicaps, poverty, and the anomic behavior of the lower classes frustrated in their drive for economic success. It permits straining after false panaceas in terms of partial solutions. It diverts solutions into areas of emotional catharsis based upon sentimentally conceived aids to the impoverished and the handicapped in a society whose technological complexities call for the highest level of rational analysis and planning. It impoverishes criminology as a field struggling to become a behavioral science by diverting its major theories from the rigorous analysis of the forces in the social and economic order that interfere with co-operative solutions of our exploitative behavior.

True enough, honest crime reporting will not go very far in substituting co-operative for exploitative approaches in American cultural behavior, but it should be one useful step in assisting the American public to rational thinking in the field of social policy on crime control. 